JIPFRI, Vol. 2 No. 1 Halaman: 21-27 Mei 2018
JIPFRI (Jurnal Inovasi Pendidikan Fisika dan Riset IImiah)

DOI: 10.30599/jipfri.v2i1.161

\title{
Pengembangan Alat Praktikum Sederhana Sebagai Media Praktikum Mahasiswa
}

\author{
Widayanti ${ }^{1^{*}}$ dan Yuberti ${ }^{2}$ \\ ${ }^{1}$ Pascasarjana Pendidikan Fisika Universitas Lampung, \\ Bandar Lampung, Lampung 35145 \\ 2Univrsitas Islam Negeri Raden Intan Lampung, \\ Bandar Lampung, Lampung 35131 \\ *Email: 1widayanti@radenintan.ac.id, ${ }^{2}$ yuberti@radennintan.ac.id
}

\begin{abstract}
Abstrak
Penelitian ini bertujuan untuk (1) mengetahui cara mengembangkan alat praktikum sederhana percobaan Melde, (2) mengetahui tingkat kelayakan alat praktikum sederhana percobaan melde. Metode yang digunakan pada penelitian ini adalah Research and Development yang diadaptasi dari Thiagarajan (4D) meliputi define, design, developt, dan dissemination. Penelitian ini dilakukan sampai pada tahap development. Hasil penelitian adalah (1) alat praktikum sederhana percobaan melde, (2) tingkat kelayakan alat praktikum sederhana percobaan melde antara lain: ahli media $86,7 \%$ dikriteriakan sangat layak. Hasil uji coba produk alat praktikum sederhana percobaan melde antara lain: uji coba satu lawan satu $83,3 \%$, uji coba kelompok kecil 87,5\%, dan uji coba lapangan $90,9 \%$ ketiga hasil uji coba dikriteriakan sangat layak. Pengembangan alat praktikum sederhana percobaan melde layak dijadikan media pembelajaran.
\end{abstract}

Kata kunci: Alat Praktikum Sederhana, Penelitian dan Pengembangan, Percobaan Melde

\begin{abstract}
This study aimed to (1) find out how to develop a simple experimental tool for Melde's experiment, (2) determine the feasibility level of simple melde's experiments. The method used in this research was Research and Development which was adapted from Thiagarajan (4D) including define, design, develop and dissemination. This research was done until the development stage. The results of the study includes the simple experimental practice of melde's experiment and the feasibility level of simple experimental tool of melde's experiment. Based on $86,7 \%$ of experts' judgement, the simple experimental tool is categorized into very feasible. The result of trial experiment in one on one, small group and fields are $83.3 \%, 87.5 \%$ and $90.9 \%$ respectively. The three experimental results were categorized into highly feasible. Thus, the development of simple experimental tools for melde's experiment is worthy as a learning media.
\end{abstract}

Keywords: Simple Practicum Tools, Research and Development, Melde Experiment

\section{PENDAHULUAN}

Kehidupan manusia terus mengalami perkembangan dalam berbagai bidang (Muhson, 2017; Ngafifi, 2014; Pitopang \& Elijonnahdi, 2011; Zamroni, 2009). Salah satunya perkembangan pada bidang pendidikan (Budiman, 2017; Çetİn, A, Güvenç, \& Sakal, 2016; Nurhayati, 2017; Saregar, 2016). Pendidikan merupakan bagian terpenting dalam kehidupan manusia (Kalida, 2016; Retnoningtias, 2017; Nurdiansyah ,
2016; Rosyadi, 2016; Junanto, 2016, Sifa, 2016, Banyumin, 2016, Arifin, K, 2013, Nurjanah, 2016), dengan pendidikan yang lebih tinggi diharapkan akan menghasilkan manusia yang berkualitas (Hasanah, 2004; Krismiyati, 2017; Rohman \& Lusiyana, 2017; Sitaresmi, Saputro, \& Utomo, 2017).

Pentingnya pendidikan terdapat dalam al-qur'an surat Al-Alaq (Q.S Al-Alaq 96: 1-19). Pembelajaran dalam pendidikan membutuhkan perantara yaitu media pembelajaran (Muhson, 2010; Supartini, 2016; Yuliandri, 2014). Media pembelajaran merupakan unsur penting dalam 
kegiatan belajar mengajar (Hidayat, 2017; Irwandani, Latifah, Asyhari, Muzannur, \& Widayanti, 2017; Wijayanti, Handhika, \& Huriawati, 2013). Media pembelajaran adalah alat bantu mengajar (Astuti, Sumarni, \& Saraswati, 2017; Matsun, Sunarno, \& Masykuri, 2016; Rezeki \& Ishafit, 2017; Yuberti \& Siregar, 2017). Salah satu media pembelajaran visual adalah Alat praktikum sederhana (Huriawati \& Yusro, n.d.). Alat praktikum adalah suatu alat yang dapat diserap oleh mata dan telinga dengan tujuan membantu pendidik agar proses pembelajaran lebih efektif dan efisien (Nana, 2010). Penggunaan alat praktikum dalam proses pembelajaran sains dapat mempermudah peserta didik memahami konsep sains (Arsyad, 2011; Desy, Desnita, \& Raihanati, 2015).

Alat praktikum sangat diperlukan pada sebuah lembaga pendidikan (Puspasari, 2017; Saepuzaman \& Yustiandi, 2017), namun belum semua pendidikan memiliki alat praktikum yang lengkap atau mewakili untuk menjelaskan materi tertentu (Wulandari, Susilo, \& Kuswandi, 2016). Materi yang bersifat abstrak dan membutuhkan alat praktikum untuk menjelaskannya yaitu materi gelombang. Salah satu yang ada pada materi gelombang adalah percobaan melde (Agustianti, Rustana, \& Nasbey, 2015).

Tujuan digunakan alat praktikum diantaranya: (1) meningkatkan pengetahuan ilmiah, (2) mengajarkan keterampilan bereksperimen, (3) mengembangkan sikap ilmiah, (4) mengembangkan keahlian dan dapat memberikan penilaian, dan (5) memotivasi peserta didik (Dewi, 2015). Adapun kriteria kelayakan alat praktikum, diantaranya (Afriyanto, 2015): (1) alat praktikum harus sesuai konsep fisika, (2) alat praktikum sesuai kurikulum, (3) performance alat praktikum harus menarik dan sesuai subjek penelitian, (4) alat praktikum mudah dipahami, dan (5) alat praktikum mudah digunakan

Berdasarkan hasil observasi semester empat dan enam jurusan pendidkan fisika di Universitas Islam Negeri Raden Intan Lampung, 40\% mahasiswa telah melakukan praktikum percobaan melde di luar kampus, $60 \%$ belum melakukan praktikum karena keterbatasan alat praktikum yang dimiliki (Widayanti, 2016).

National Training Laboratories menemukan fakta bahwa pelajar hanya dapat mengingat materi pelajaran sebanyak $5 \%$ hingga $10 \%$ dari yang mereka baca di dalam buku bacaan, tetapi mereka dapat mengingat hingga $80 \%$ dari yang telah mereka alami/kerjakan (Egarievwe, 2015; Mustami, 2017). Praktikum salah satu kegiatan pembelajaran yang dapat dikerjakan secara langsung. Diharapkan tersedianya alat praktikum peserta didik dapat mengingat lebih lama.

Berdasarkan pemaparan tersebut peneliti merasa perlu untuk mengembangkan alat praktikum sederhana percobaan melde sebagai media pembelajaran. Novelty dari penelitian yang relevan alat praktikum percobaan melde yang peneliti kembangkan menggunakan alat dan bahan sederhana sehingga alat praktikum percobaan melde lebih efektif dan efisien.

\section{METODE/EKSPERIMEN}

\section{Prosedur Penelitian}

Penelitian ini adalah penelitian dan pengembangan (Research and Development), dengan metode kualitatif dan kuantitatif (mixed method). Metode penelitian di adopsi dari Thiagarajan (4D) (Akhlis \& Dewi, 2013; Sivasailam, Semmel, \& Semmel, 1974), adapun tahapan penelitian terdiri dari 4 tahap, meliuti: (1) define, (2) design, (3) develop, dan (4) disseminate. Pada penelitian ini sampai pada tahap ketiga, karena pada penelitian tidak mengukur tingkat keefektifan produk yang dikembangkan. Adapun prosedur pada penelitian ini sebagaimana pada gambar 1 .

Tahap pelaksanaan dalam penelitian meliputi: (1) peneliti melakukan analisis permasalahan melalui kuesioner yang dibagikan pada semester 4 dan semester 6 tahun 2016 UIN Raden Intan Lampung yakni menetapkan dan mendefinisikan syarat-syarat pembelajaran yang diawali dengan analisis tujuan dari batasan materi yang dikembangkan. (2) peneliti mendesain produk yang 


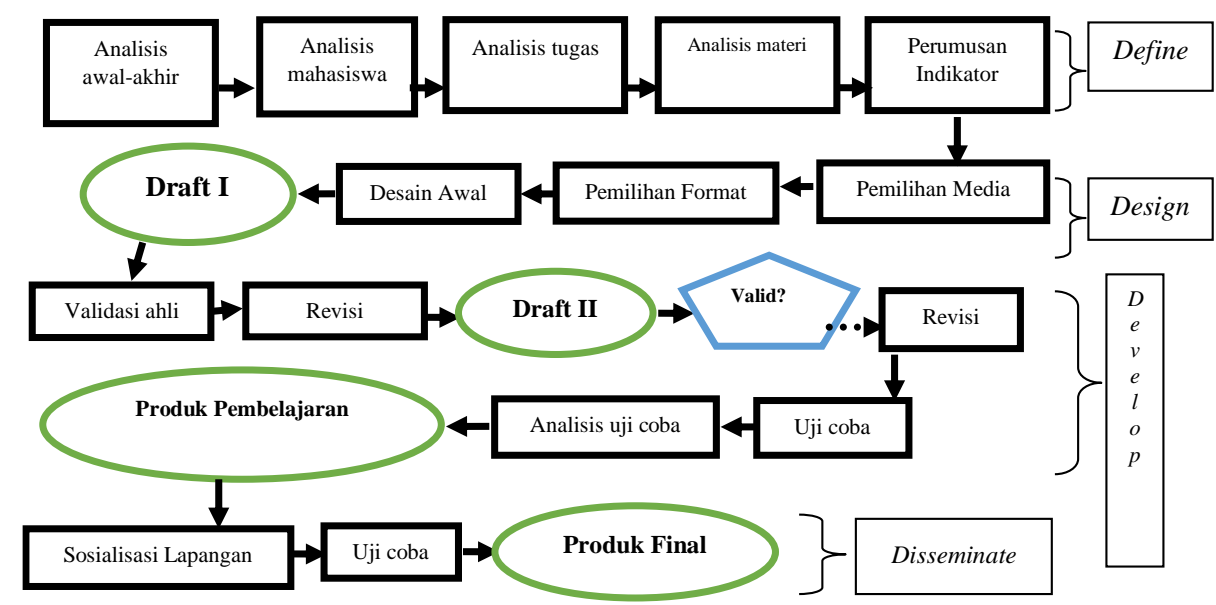

Gambar 1. Langkah-langkah Penelitian.

dikembangkan. Selain itu, peneliti menyusun instrumen pengukur kelayakan produk baik untuk validator maupun untuk responden. Instrumen yang telah disusun kemudian divalidasi oleh validator. (3) validasi ahli terkait produk yang dikembangkan, melakukan revisi hingga produk memenuhi kriteria kelayakan. Kemudian melakukan uji coba. Penelitian ini dilakukan di UIN Raden Intan Lampung, semester 4 kelas $A$ dan $B$, melalui 3 uji coba yaitu uji coba satu lawan satu, uji coba kelompok kecil, dan uji coba lapangan (Setyosari, 2012).

\section{Analisis Data}

Teknik pengumpulan data dalam penelitian ini menggunakan kuesioner, meliputi: kuesioner observasi, kuesioner validator instrumen, kuesioner validasi produk, dan kuesioner respon. Analisis data yang digunakan dalam penelitian ini sebagai berikut:

Analisis rata-rata validator instrumen dan validator produk (A. L. Hakim, Munzil, \& Parlan, n.d.; I. Hakim, Liliasari, Kadarohman, \& Syah, 2016):

$$
\bar{V}=\frac{\sum V}{n}
$$

Dengan kriteria sebagai berikut:

Tabel 1. Kriteria Validasi

\begin{tabular}{|c|c|}
\hline Rata-rata & Kriteria Validasi \\
\hline $4,20 \leq V \leq 5,00$ & Sangat Valid \\
\hline $3,40 \leq \mathrm{V}<4,20$ & Valid/ Tidak Revisi \\
\hline $2,60 \leq V<3,40$ & Cukup Valid/ Tidak Revisi \\
\hline $1,80 \leq \mathrm{V}<2,60$ & Kurang Valid/ Sebagian Revisi \\
\hline $1,00 \leq \mathrm{V}<1,80$ & Tidak Valid/ Revisi Total \\
\hline
\end{tabular}

kuesioner adalah (Riduan, 2002):

$$
P=\frac{\sum \operatorname{skor} x f}{\text { Skor tertinggi }} \times 100 \%
$$

Dengan kriteria sebagai berikut:

Tabel 2. Kriteria Persentase

\begin{tabular}{ccc}
\hline Skor & $\begin{array}{c}\text { Tingkat } \\
\text { Pencapaian (\%) }\end{array}$ & Kualifikasi \\
\hline 5 & $80<\mathrm{V} \leq 100$ & Sangat Layak \\
4 & $60<\mathrm{V} \leq 80$ & Layak \\
3 & $40<\mathrm{V} \leq 60$ & Cukup Layak \\
2 & $20<\mathrm{V} \leq 40$ & Kurang Layak \\
1 & $0 \leq \mathrm{V} \leq 20$ & Tidak Layak \\
\hline
\end{tabular}

\section{HASIL DAN PEMBAHASAN}

Penelitian ini menghasilkan alat praktikum sederhana percobaan melde yang telah memenuhi kriteria kelayakan. Tahap pendefinisian bertujuan untuk menetapkan dan mendefinisikan syarat-syarat pembelajaran dengan menganalisis tujuan dan materi yang akan dikembangkan. Pada tahap pendefinisian peneliti melakukan beberapa tahapan, yaitu analisis awal-akhir, analisis mahasiswa, analisis tugas, analisis materi dan perumusan indikator. Kemudian analisis materi dilakukan dengan memberikan kuesioner terbuka kepada asisten praktikum mekanika. Dari hasil kuesioner tersebut mahasiswa yang belum melakukan praktikum percobaan melde karena keterbatasan alat praktikum, sehingga perlu untuk mengembangkan alat praktikum sederhana percobaan melde sebagai media pembelajan.

Tahap perancangan bertujuan untuk 
mendapatkan draft I produk pembelajaran yang akan dikembangkan. Pada tahap ini sebagai acuan untuk merancang desain produk yang akan dikembangkan. Kegiatan yang dilakukan meliputi pemilihan media untuk mengembangkan media yang sesuai dengan masalah penelitian, pemilihan format tujuannya agar produk yang akan dikembangkan memiliki konsep yang sesuai dengan subjek penelitian, dan merealisasikannya pada desain awal. Kegiatan tersebut yang menghasilkan draft I.

Tahap pengembangan merupakan tahapan dalam menghasilkan darft II dan produk pembelajaran. Kegiatan yang dilakukan pada tahap pengembangan adalah validasi produk kepada validator. Pada darft I ada beberapa yang harus direvisi oleh peneliti. Oleh karena itu, hasil revisi darft I menghasilkan darft II. Berdasarkan penilaian validator terhadap alat praktikum sederhana percobaan melde yang telah dikembangkan dinyatakan sangat layak dengan persentase akhir $86,7 \%$. Alat praktikum sederhana percobaan melde sebagai media pembelajaran sebagaimana pada gambar 2 .

Langkah selanjutnya adalah melakukan uji coba alat praktikum sederhana percobaan melde. Peneliti melakukan tiga uji coba. Diantaranya uji coba satu lawan satu, uji coba kelompok kecil, dan uji coba lapangan. Seluruh subjek uji coba di ambil mahasiswa semester 4 UIN Raden Intan Lampung, uji coba satu lawan satu adalah tiga mahasiswa kelas, yang memiliki IPK tertinggi, sedang, dan terendah dikelas tersebut. adapun uji coba satu lawan satu alat praktikum sederhana percobaan melde diperoleh hasil 83,3\% dinyatakan sangat layak. Subjek uji coba kelompok kecil adalah delapan mahasiswa semester kelas diluar mahasiswa sampel uji coba satu lawan satu. Uji coba kelompok kecil pada alat praktikum sederhana percobaan melde diperoleh $87,5 \%$ dinyatakan sangat layak. Uji coba yang terakhir uji coba lapangan, subjek uji coba lapangan adalah tiga puluh mahasiswa kelas B. Uji coba lapangan pada alat praktikum sederhana percobaan melde diperoleh $90,9 \%$ dinyatakan sangat layak.

Perbandingan persentase rata-rata uji coba satu lawan satu, uji coba kelompok kecil dan uji coba lapangan pada alat praktikum sederhana percobaan melde di tunjukkan pada gambar 3.

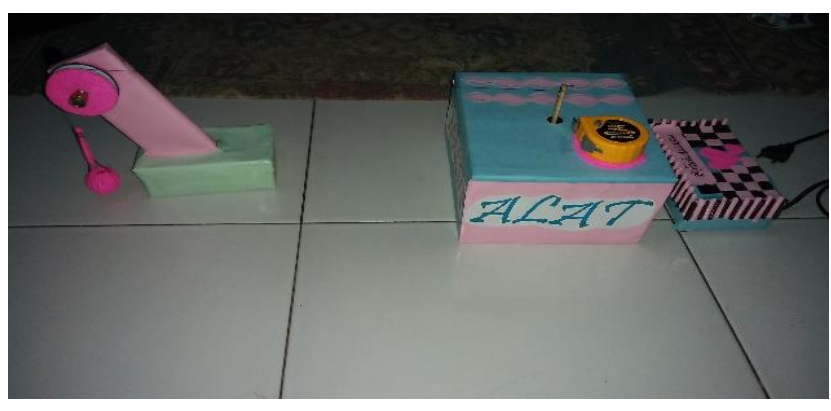

(a)

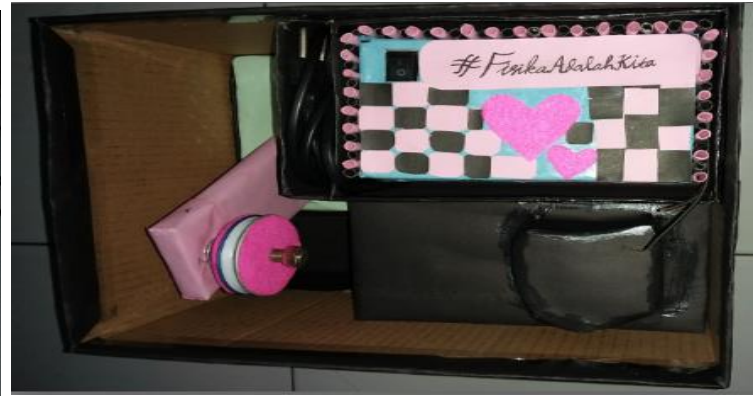

(b)

Gambar 2. (a) Alat praktikum sederhana percobaan melde. (b) Rangkain alat praktikum sederhana percobaan melde pada box 


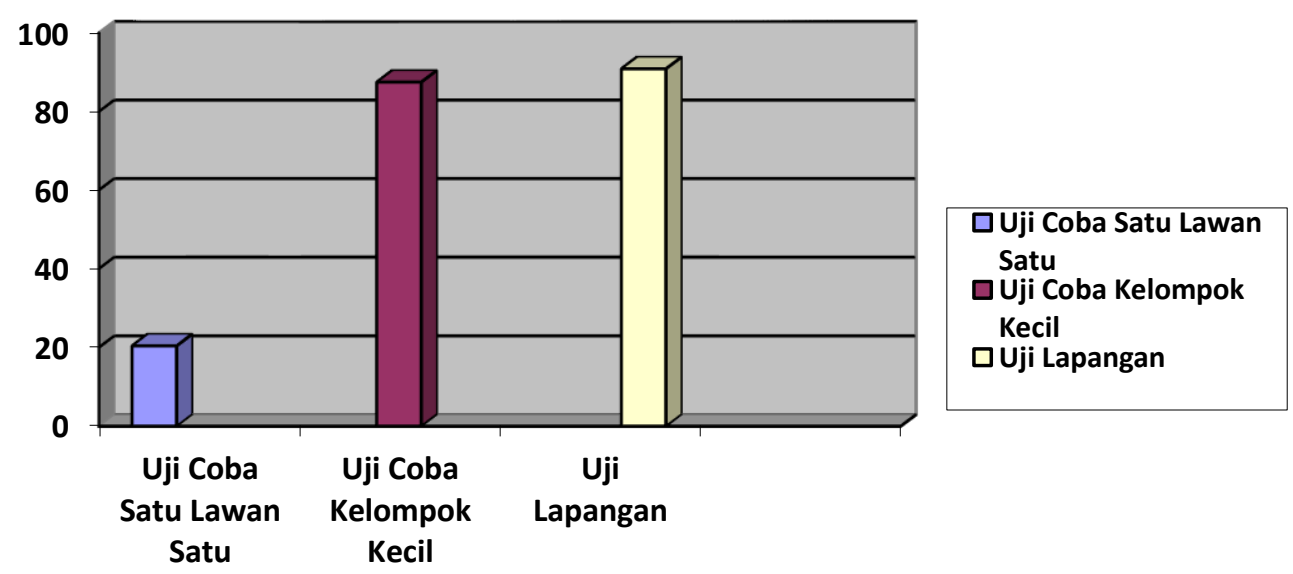

Gambar 3. Perbandingan Uji coba Alat Praktikum Sederhana Percobaan Melde

\section{PENUTUP}

\section{Kesimpulan}

Penelitian ini Menghasilkan produk berupa alat praktikum sederhana percobaan Melde. Pengembangan alat praktikum sederhana percobaan melde dinyatakan layak. Persentase pada masing-masing hasil penelitian yaitu validasi media $86,7 \%$, uji coba satu lawan satu 83,3\%, uji coba kelompok kecil $87,5 \%$, dan uji coba lapangan $90,9 \%$. Alat praktikum percobaan Melde menggunakan alat dan bahan sederhana dan lebih efisien.

\section{Saran}

Saran untuk penelitian selanjutnya sebaiknya menggunakan alat praktikum sederhana percobaan melde dan sebaiknya mahasiswa berinisiatif untuk menciptakan alat praktikum saat alat dan bahan tidak tersedia dilaboratorium

\section{DAFTAR PUSTAKA}

Afriyanto, E. (2015). Pengembangan Media Pembelajaran Alat Peraga pada Materi Hukum Biot Savart di SMAN 1 Prambanan Klaten. JRKPF UAD, 2(1), 20-24.

Agustianti, D., Rustana, C. E., \& Nasbey, H. (2015). Pengembangan Alat Praktikum Melde Sebagai Media Pembelajaran Fisika SMA. Prosiding Seminar Nasional Fisika (E-Journal) SNF2015, IV, 45-48.
Akhlis, I., \& Dewi, N. R. (2013). Pengembangan Perangkat Pembelajaran Science Berorientasi Cultural Deviance Solution Berbasis Inkuiri Menggunakan ICT Untuk Mengembangkan Karakter Peserta Didik. Jurnal Pendidikan IPA Indonesia, 2(2), 203-208.

https://doi.org/10.15294/jpii.v4i2.4179

Arsyad, A. (2011). Media Pembelajaran. Jakarta: Rajawali Press.

Astuti, I. A. D., Sumarni, R. A., \& Saraswati, D. L. (2017). Pengembangan Media Pembelajaran Fisika Mobile Learning berbasis Android. JPPPF - Jurnal Penelitian \& Pengembangan Pendidikan Fisika, 3(1), 57-62.

Budiman, H. (2017). Peran Teknologi Informasi dan Komunikasi dalam Pendidikan. AlTadzkiyyah: Jurnal Pendidikan Islam, 8, 75-83.

Çetin, G., A, O. Ö., Güvenç, E., \& Sakal, M. (2016). The Development Of An EBook With Dynamic Content For The Introduction Of Algorithms And Programming. Mugla Journal of Science and Technology, 2(2), 199-203.

Desy, Desnita, \& Raihanati. (2015). Pengembangan Alat Peraga Fisika Materi Gerak Melingkar untuk SMA. Prosiding Seminar Nasional Fisika (E-Journal) SNF2015, IV, 39-44.

Dewi, M. L. (2015). Pengembangan Modul Praktikum Fisika Berbasis Data Logger untuk SMA. Prosiding Seminar Nasional Fisika (E-Journal) SNF 2015. 
Egarievwe, S. U. (2015). Vertical Education Enhancement - A Model for Enhancing STEM Education and Research. Procedia - Social and Behavioral Sciences, 177, 336-344.

https://doi.org/10.1016/j.sbspro.2015.02. 354

Hakim, A. L., Munzil, \& Parlan. (n.d.). Pengembangan Media Pembelajaran Berbasis Learning Management System (LSM) pada Materi Senyawa Karbon untuk SMA Kelas XII. Jurusan Kimia FMIPA, 3.

Hakim, I., Liliasari, Kadarohman, A., \& Syah, A. M. (2016). Improvement of Student Critical Thinking Skills with the Natural Product Mini Project Laboratory Learning. Indones. J. Chem, 16(3), 322-328.

Hasanah, U. (2004). Kemitraan Antara Dunia Industri dan Pendidikan dalam Pengembangan SDM PTK. Seminar Internasional, 613-620.

Hidayat, A. (2017). Pengembangan Buku Elektronik Interaktif Pada Materi Fisika Kuantum Kelas XII SMA. Jurnal Pendidikan Fisika, 5(5), 87-101.

Huriawati, F., \& Yusro, A. C. (n.d.). Pengembanagan Odd "Osilator Digital Detector" sebagai Alat Peraga Praktikum Gerak Harmonik Sederhana. Jurnal Inovasi Dan Pembelajaran Fisika, 1-8.

Irwandani, Latifah, S., Asyhari, A., Muzannur, \& Widayanti. (2017). Modul digital interaktif berbasis articulate studio'13: pengembangan pada materi gerak melingkar kelas $x$. Jurnal Ilmiah Pendidikan Fisika Al-Biruni, 6(2), 221231.

https://doi.org/10.24042/jpfalbiruni.v6i2.1 862

Krismiyati. (2017). Pengembangan Sumber Daya Manusia dalam Meningkatkan Kualitas Pendidikan di SD Negeri Inpres Angkasa Biak. Jurnal Office, 3(1), 43-50.

Matsun, Sunarno, W., \& Masykuri, M. (2016). Penggunaan Laboratorium Riil dan Virtual pada Pembelajaran Fisika dengan Model Inkuiri Terbimbing Ditinjau dari Kemampuan Matematis dan Keterampilan Berpikir Kritis. Jurnal Pendidikan Fisika, 4(2), 137-152.

Muhson, A. (2010). Pengembangan Media
Pembelajaran Berbassis Teknologi Informasi. Jurnal Pendidikan Akutansi Indonesia, 8(2), 1-10.

Muhson, A. (2017). Pengembangan Media Pembelajaran Berbasis Moodle Pada Matakuliah Fisika Dasar Lovy. Jurnal Pendidikan Akuntansi Indonesia, 36(1), 210-219. Retrieved from http://journal.uny.ac.id/index.php/jpakun/ article/view/949

Mustami, M. K. (2017). Validitas Pengembangan Penuntun Praktikum llustratif Mikroteknik Hewan Berbasis Guided Inquiry. Jurnal IImiah Pena Volume, 11(1), 75-83.

Nana, S. (2010). Dasar-dasar Proses Pembelajaran. Bandung: Sinar Baru.

Ngafifi, M. (2014). Kemajuan Teknologi dan Pola Hidup Manusia dalam Perspektif Sosial Budaya. Jurnal Pembangunan Pendidikan: Fondasi Dan Aplikasi, 4(1), 33-47.

Nurhayati, D. (2017). Pengembangan Buku Digital Interaktif Mata Kuliah Pengembangan E-Learning Pada Mahasiswa Teknologi Pendidikan FIP UNY. E-Jurnal Prodi Teknologi Pendidikan Vol., VI(5), 458-473.

Pitopang, R., \& Elijonnahdi. (2011). Aplikasi IImu Biologi Dalam Pendidikan dan Pembangunan Berwawasan Lingkungan Berbasis Sumberdaya Alam. Biocelebes, 5(2), 105-116.

Puspasari, R. (2017). Implementasi Project Based Learning Untuk Meningkatkan Kemandirian Dan Prestasi Belajar Mahasiswa Dalam Pembuatan Alat Peraga Matematika Inovatif. Math Didactic: Jurnal Pendidikan Matematika, 3(1), 10-22.

Rezeki, S., \& Ishafit. (2017). Pengembangan Media Pembelajaran Interaktif untuk Sekolah Menengah Atas Kelas XI pada Pokok Bahasan Momentum. JPPPF Jurnal Penelitian \& Pengembangan Pendidikan Fisika, 3(1), 29-34.

Riduan. (2002). Skala Pengukuran Variabelvariabel Penelitian. Bandung: Alfabeta.

Rohman, F., \& Lusiyana, A. (2017). Pengembangan Modul Praktikum Mandiri Sebagai Asesmen Keterampilan Proses 
Sains dan Keterampilan Sosial Mahasiswa. JIPFRI: Jurnal Inovasi Pendidikan Fisika Dan Riset IImiah, 1(2), 47-56.

Saepuzaman, D., \& Yustiandi. (2017). Pengembangan Alat Peraga dan Lembar Kerja Percobaan Penentuan Koefisien Restitusi untuk Meningkatkan Kemampuan Siswa Bereksperimen. JPPPF - Jurnal Penelitian \& Pengembangan Pendidikan Fisika, 3(2), 145-150.

https://doi.org/10.21009/1.03204

Saregar, A. (2016). Pembelajaran Pengantar Fisika Kuantum dengan Memanfaatkan Media PhET Simulation Dan LKM Melalui Pendekatan Saintifik: Dampak Pada Minat Dan Penguasaan Konsep Mahasiswa. Jurnal IImiah Pendidikan Fisika Al-Biruni, 5(1), 53-60. https://doi.org/10.24042/jpifalbiruni.v5i1.1 05

Setyosari, P. (2012). Metode Penelitian Pendidikan dan Pengembangan. Jakarta: Kencana.

Sitaresmi, K. S., Saputro, S., \& Utomo, S. B. (2017). Penerapan Pembelajaran Project Based Learning (PjBL) untuk Meningkatkan Aktivitas dan Prestasi Belajar Siswa pada Materi Sistem Periodik Unsur (SPU) Kelas X MIA 1 SMA Negeri 1 Teras Boyolali Tahun Pelajaran 2015/2016. Jurnal Pendidikan Kimia, 6(1), 54-61. Retrieved from http://jurnal.fkip.uns.ac.id/index.php/kimia /article/view/9405

Sivasailam, T., Semmel, D. S., \& Semmel, M. I. (1974). Instructional Development for Training Teachers of Exceptional Children: A Sourcebook. Leadership Training Institute/Special Education: University of Minnesota Hooley.

Supartini, M. (2016). Pengaruh Penggunaan Media Pembelajaran Dan Kreativitas Guru Terhadap Prestasi Belajar Siswa Kelas Tinggi Di SDN Mangunharjo 3 Kecamatan Mayangan Kota Probolinggo. Jurnal Penelitian Dan Pendidikan IPS (JPPI), 10(2), 277-293.

Widayanti. (2016). Observasi Pendidikan Fisika Universitas Islam Negeri Radn Intan. Bandar Lampung.

Wijayanti, G., Handhika, J., \& Huriawati, F.
(2013). Pengembangan Modul Berbasis Alam pada Pokok Bahasan Kalor, (85), 61-65.

Wulandari, R., Susilo, H., \& Kuswandi, D. (2016). Multimedia Interaktif Bermuatan Game Edukasi Sebagai Salah Satu Alternatif Pembelajaran IPA Di Sekolah Dasar. Jurnal Pendidikan, 1-8.

Yuberti, \& Siregar, A. (2017). Pengantar Metodologi Penelitian Pendidikan Matematika dan Sains. Bandar Lampung: Anugrah Utama Raharja.

Yuliandri, S. (2014). Pengembangan Media Pembelajaran Berbasis Multimedia Interaktif pada Mata Pelajaran Ekonomi Materi Jurnal Penyesuaian Perusahaan Jasa. Universitas Negeri Surabaya2, 1-9.

Zamroni, M. (2009). Perkembangan Teknologi Komunikasi dan Dampaknya Terhadap Kehidupan. Jurnal Dakwah, 10(2), 195211. 